Studia Slavica Savariensia 2016. 1-2. 274-281

DOI: $10.17668 /$ SSS.2016.1-2.274

\author{
Живка Колева-Златева \\ (Велико Тырново, Болгария)
}

\title{
ОБ ОДНОЙ ГРУППЕ СЛАВЯНСКИХ НАЗВАНИЙ КАРТОФЕЛЯ
}

\begin{abstract}
The article examines series of Slavic denominations of potato containing reduplicated clusters of sounds. A hypothesis for sound-symbolic origin of the words is presented. The following data were taken into account: the formal and semantic parallelism between words with reduplication expressing the same meaning, their formal and semantic variation, formal irregularities, contamination.
\end{abstract}

Keywords: Slavic languages, etymology, reduplication, sound-symbolic origin

\section{1. Немного истории}

Картофель распространяется в Европе с XVI века, куда был завезен из Южной Америки испанскими мореплавателями завоевателями. В изданных ими путевых записках или хрониках они упоминают о корнях, именуемых индейцами papas, похожих на каштаны (ANDAGOYA 1865: 74) или на трюфели (turmas de tierra), которые, «будучи сварены, становятся мягкими внутри, как сваренные каштаны» (CIEZA DE LEÓN 2005: 115). В европейских странах новый овощ принимали с недоверием. Как отмечает В.В. Григорьев в своем «Руководстве к ботанике», «весьма замечательно то, что кофе и табак, несмотря на все запрещения, весьма быстро распространился в Европе, тогда как картофель, несмотря на все поощрения, долго встречал в народном суеверии и предрассудках сильное сопротивление» (ГРИГОРЬЕВ 1861: 232). В «Энциклопедическом словаре» Ф.А. Брокгауза, И.А. Ефрона тоже отмечено, что на протяжении первого столетия после того, как был завезен в Европу, «картофель распространялся довольно туго, особенно в Восточной Европе» (БРОКГАУЗ - ЕФPOH 1895: 625).

Индейское название картофеля было заимствовано только в испанском языке. В Италии картофель был назван tartufo, tartufolo «трюфель» из-за сходства с трюфелями. Итальянское название было заимствовано немцами, которые сначала назвали картофель Tartuffel, и это слово впоследствии диссимилировалось в Kartoffel, заимствованное рядом языков, в том числе и славянскими, ср.: русск. карто́фель, укр. карто́nля, словацк. диал. kartofel, польск. kartofel, сербохорв. kritōla, рум. cartóf, болг. картó ф, алб. kartole и др. (MEW: 112; KLUGE 1889: 162). Другое, широко заим- 
ствованное название картофеля - это исп. potato, batata, которое само является заимствованием названия batata из местного индейского языка,

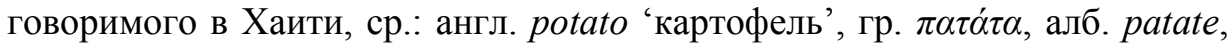
болг. диал. пата̀ти мн. 'картофель', чешск. диал. batat, batata и др. (OED; БEP, V: 92; PSJČ). Во Франции назвали картофель ротте de terre «земляное яблоко», калькированное и русским земляное яблоко, чешским диал. zemské jabličko (ДАЛЬ; PSJČ). Аналогичным названием является и нем. диал. Grundbirne, буквально «земляная груша», первоначально означающее Helianthus tuberosus, a c XVIII в. - и картофель, калькированное чешским диалектным zemská hruška (PSJČ), заимствованное и в других языках, ср.: чешск. krumpir, словацк. krumpel', польск. диал. kuтpery, словен. krompir, сербохорв. кру̀мпир, болг. диал. крумпир, рум. диал. сruтр, венг. krumpli и др. (цит. по БЕР, III: 25-26). Отметим, что заимствование названий для картофеля, в том числе и славянскими языками, вполне естественно, имея в виду сам процесс заимствования новой реалии.

\section{2. Славянские названия картофеля с редупликацией}

Славянские языки прибегали к называнию картофеля не только заимствованными или образованными по чужим моделям наименованиями. $\mathrm{B}$ настоящей статье рассмотрим исконные славянские названия картофеля. И это такие названия, в звуковой форме которых можно усмотреть редупликацию - полную (типов: CV-CV; CVR-CVR; CR-CR) или неполную (типов: CV-CVR; CVR-C), в некоторых случаях затемненную диссимиляцией, закономерными фонетическими изменениями или экспрессивным развитием. Ср. следующие названия:

словен. $b \grave{o}-b^{l}$ 'картофель' (PLETERŠNIK, I: 36), сербохорв. $b o ́-b-a$ 'клубень картофеля' (RJA, I: 463), болг. диал. влашки бо-б (СТОЙКОВ 1993: 307);

укр. диал. бом-бу́ль-ка, бом-бов-ка (<*бом-бол-ка) 'плод картофеля' (цит. по ЕСУМ, I: 228), бам-бу́ль-ка 'круглая ягода (на ботве картофеля)' (ГРИНЧЕНКО, І: 26), н.-луж. bam-bul-ka 'ягодка картофельного цветка' (MUKA, I: 12), чешск. диал. bam-bol, bam-b-och (цит. по KORANDOVÁ 1962: 183), словен. bọm-b-ek 'мелкие клубни картофеля для посадки' (PLETERSNIK, I: 45);

укр. бала-ба́н-ка 'очень крупный сорт картофеля', бала-бо́н-ка 'род растения с клубнями на корне, похожими на картофель' (ГРИНЧЕНКО, I: 23), диал. бала-бон 'то же', польск. диал. bata-bon, bała-bun, bata-ban, bała-baj-a, bała-baj-ka 'клубень картофеля' (цит. по ЕСУМ, I: 122), укр. диал. бара-бу́л-я, бара-бо́н-я, бара-біль, бара-бій, бара-бін, бара-бо́н, бара-бо́л-я, бала-бу́р-ка 'картофель' (цит. по ЕСУМ, I: 137), болг. диал. бара-бо́й, бара-бо́й-ки, бар-бо́й, бр-бой, бра-бо́й, бръ-бо́й 'картофель' (цит.

\footnotetext{
${ }^{1}$ Усмотренные редуплицированные звуковые комплексы выделены дефисом. В некоторых случаях указаны варианты.
} 
по БЕР, I: 32), брь-бо́й 'то же' (ГЕРОВ, I: 75), польск. диал. bała-bur-ka 'вид картофеля', bara-bol-a 'то же' (WARSZ., I: 89, 96), укр. диал. барабол-я 'земляная груша' (цит. по ЕСУМ, I: 138, где название представлено как результат перенесения названия картофеля из-за сходства между обозначаемыми объектами), русск. диал. бала-бо́л-ка, бала-бо́ш-ка, бала-бе́ш$\kappa a$, 'плод картофеля с семенами, вырастающий на стебле после цветения', бара-бу́л-я 'картофель, клубни картофеля', бара-бо́ш-ки мн. 'то же', болбы́ш обычно мн. 'плоды картофеля, растущие на стеблях' (СРНГ, ІІ: 6566, 68,102; III: 71), бара-бо́л-я 'картофель', бара-бо́ш-ка 'земляное или чертово яблоко' (ДАЛЬ) - здесь и далее некоторые формы с экспрессивным изменением $л>w$;

болг. диал. барам-бо́й, брам-бо́й, бръм-бо́й, бръ́м-бол-е, бръ́м-бул-е 'картофель' (цит. по БЕР, I: 32), чешск. bram-bor, диал. bram-bor-a, brambor-o, bram-bur / bram-búr, bram-bur-a / bram-búr-a, bran-bor, brani-bor, brant-bor-a; ban-dor, ban-dur / ban-dúr, ban-dor-a, словацк. диал. bumbur-y, ban-dur, ban-dor, польск. диал. bram-ber-y, bram-br-y (KORANDOVÁ 1962: 183, 185) - возможно, здесь результат контаминации форм типа *bam-bul-/*bam-bur и *bar-bor/*bar-bol/*bar-boj;

русск. диал. бо-бу́ль-ка 'наземный плод картофеля, образующийся из цветка', бо́-быш-ки (бо́-б-ышки) мн. 'плоды картофеля', ба-бо́ш-ка 'плод картофеля' (СРНГ, III: 40; II: 27), укр. диал. бо-ба́ль-ки, бо-ба́н-я (боб-áня) ‘мелкий картофель' (цит. по РУ ДНИЦЬКИЙ, I: 128), в.-луж. bo-bl-e мн. 'зеленые плоды на стебле картофеля' (PFUHL: 34), н.-луж. bo-bul-e мн. 'клубни картофеля' (MUKA I: 55), словацк. bo-bál 'картофелина' (цит. по MACHЕК 1968: 59), укр. диал. бу́-бл-яхи 'плоды картофеля, растущие на стебле' (цит. по ЕСУМ, І: 274);

укр. диал. бу-га́й-ка 'сорт картофеля' (цит. по ЕСУМ, I: 276) - форма с диссимиляцией: $\sigma-\sigma>\sigma-2$;

польск. bul-b-a 'картофель' (WARSZ., I: 232), белорусск. бу́ль-б- $a$ 'то же' (БАЙКОЎ - НЕКРАШЭВІЧ 1925), укр. бу́ль-б-а 'картофель', диал. 'мелкий картофель', русск. бу́ль-б- $a$ 'картофель', бу́нь-б- $a$ 'картофель; земляное или чертово яблоко’ (цит. по ЕСУМ, І: 291);

укр. диал. бу́ль-м-а, буль-ма́н (буль-м-а́н) 'картофель' (цит. по ЕСУМ, І: $291)$ - формы с диссимиляцией: $\sigma-\sigma>\sigma-м)$;

чешск. bul-v-a 'свекловица; картофелина' (цит. по МАCHЕК 1968: 76), словацк $b u l$ - $v$-a 'корнеплод, картофелина', польск. $b u l-w$ - $a$ 'картофелина', укр. диал. бу́ль-в- $а$ 'луковица; картофелина' (цит. по ЕСУМ, І: 292) формы с диссимиляцией: $\sigma-\sigma>\sigma-6$;

укр. диал. бу́p-б- $а$, бу́ру-б- $a$ 'картофель' (цит. по ЕСУМ, I: 298);

укр. диал. тал-Іа́н (тал-І-áн) 'картофель' (цит. по ЕСУМ, I: 459);

укр. диал. тала-т-о́да 'картофель' (цит. по ЕСУМ, І: 456);

польск. диал. gara-gol-a 'картофель', укр. диал. tapa-tóл-я, tapa-бо́л-я 'то же' (цит. по ЕСУМ, I: 137, 470) - последняя форма с диссимиляцией 
консонантов: $\tau-\tau>t-\sigma$ или результат контаминации, как указано в EСУМ (I: 470);

русск. диал. гуль-б-и́на 'картофель' (СРНГ, VII: 198) - форма с диссимиляцией: $\sigma-\sigma>2-\sigma$;

польск. диал. gor-dzol-a 'вид картофеля' (WARSZ., I: 877), укр. гордзо́л-я 'картофель' (ЖЕЛЕХОВСКИЙ - НЕДЇЛЬСКИЙ, I: 169) - форма с диссимиляцией консонантов: $t-\tau>t-\partial з$ или с экспрессивной палатализацией $t>\tau^{\prime}>\partial 3$;

укр. диал. кара-ку́л-я 'картофелина', польск. диал. kara-kul-a 'то же' (цит. по ЕСУМ, II: 384);

русск. диал. коло-ко́ш-ки мн. 'наземные плоды картофеля, образующиеся после цветения' (СРНГ, XIV: 168);

н.-луж. kul-k-a 'картофель' (MUKA, I: 740);

польск. диал. mar-mol-aki мн. 'вид картофеля’ (WARSZ., II: 883);

польск. диал. mar-mur-ki мн. 'вид картофеля’ (WARSZ., II: 884).

Для некоторых слов из данного перечня высказывались мнения о заимствовании. Например, многими авторами выражается точка зрения о заимствовании наименования немецкого города Брандербурга через посредство его чешского наименования Бранибор, например для чешск. brambor, brambora (REJZEK 2001: 88-89), болг. диал. барабо́й, барабо́йки, барбо́й, брбой, брабо́й, бръбо́й, барамбо́й, брамбо́й, бръмбо́й, бръмболе, бръмбуле 'картофель' (БЕР, I: 32; СТОЙКОВ 1993: 305), укр. диал. барабу́ля, барабо́ня, барабіль, барабій, барабін, барабо́н, барабо́ля, балабурка 'картофель', польск. диал. garagola 'картофель', укр. диал. гараго́ля, гарабо́ля 'то же' (ЕСУМ, I: 137). Если учесть весь перечень названий картофеля с редупликацией и выражаемые ими и другие значения (см. ниже), такая гипотеза выглядит маловероятной.

\section{3. Формально-семантический анализ}

Кроме редупликации, в данных рядах слов можно наблюдать также формальную вариативность. Ср., например:

польск. диал. bałabon, bałabun, bałaban, bałabaja, bałabajka, укр. балаба́нка, балабо́нка;

укр. диал. барабу́ля, барабо́ня, барабіль, барабій, барабін, барабо́н, барабо́ля, балабу́рка;

русск. диал. барабу́ля, барабо́ля;

болг. диал. барамбо́й, брамбо́й, бръмбо́й, бри'мболе, брв́мбуле;

чешск. brambor, диал. brambora, bramboro, brambur / brambúr, brambura / brambúra, branbor, branibor, brantbora; bandor, bandur / bandúr, bandora;

польск. диал. marmolaki, marmurki.

Формальная вариативность дополняется случаями незакономерного фонетического развития. Ср.: 


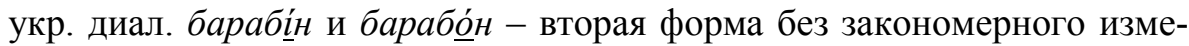
нения $[o:]>[i]$ в результате компенсаторного удлинения гласного $[o]$ после выпадения краесловного $b$;

чешск. brambor и диал. brambur / brambúr; чешск. диал. bandor и bandur / bandúr - отсутствие закономерного изменения [o:] > [u:] в результате компенсаторного удлинения гласного [o] в brambor и bandor после выпадения краесловного $b$;

укр. диал. бомби́лька, н.-луж. bambulka, словен. bômbek - формы без монофтонгизации дифтонга *om / *am

К формальным особенностям слов следует также отнести отмеченные выше случаи контаминации, которые способствуются относительным единообразием форм, и случаи экспрессивного развития: изменения $л$ $>m$. О гипокористической функции согласного $z$ в изменениях, не обусловленных фонетическими законами, см. (MALKIEL 1990: 159).

Наблюдается также вариативность семантики. Цитированные слова называют не только картофель, но и другие небольшие шарообразные предметы, как: ягоды, пузыри, шишки, экскременты овцы, козы, шарообразные цветочки, изделия из теста и др. Ср. значения следующих слов:

сербохорв. $b o ́ b a$ 'клубень картофеля' и 'что-либо маленькое, округлое', 'маленькая бородавка на голове, например, у индюшат', 'маленький камешек' (RJA, I ECУM, I: 291: 463), укр. бібка 'шарик маленький' (ГРИНЧЕНКО, I: 59);

н.-луж. bobule мн. 'клубни картофеля' и 'экскременты овцы, козы' (MUKA I: 55), чешск. bobule 'ягода' (PSJČ), словацк. bobul'a 'то же' (SSJ, I: 109), болг. диал. бо́були 'кукуруза' (БЕР, І: 60);

укр. бу́льба 'картофель', диал. 'мелкий картофель' и укр. бу́льба 'земляная груша, Helianthus tuberosus L.', диал. 'репа, Brassica campestris L.' (цит. по ЕСУМ, I: 291);

болг. диал. бръ'мбуле 'картофель' и бръ'мбул 'водяной пузырь, образующийся вследствие бросания камня в воду' (МЛАДЕНОВ 1967: 42);

укр. диал. бомбу́лька 'плод картофеля' и 'маленький шарообразный предмет' (цит. по МАСНЕК 1968: 44)

укр. диал. барабо́ля 'картофель' и барабольки́ 'лютики', барабольки́, барболькиं 'норичник' (цит. по ЕСУМ, I: 138);

болг. диал. брбой, брабо́й, бръбо́й, брьбо́й 'картофель' и брьбойка 'можжевеловая ягода' (ГЕРОВ, I; 75)

укр. диал. боба́льки 'мелкий картофель' и 'клецки, род галушек' (ЖЕЛЕХОВСКИЙ-НЕДЇЛЬСКИЙ, I: 35);

укр. диал. буга́йка 'сорт картофеля’ и буга́й ‘вид фасоли', 'сорт яблок' (цит. по ЕСУМ, I: 276);

укр. диал. бу́рба, бу́руба 'картофель' и 'круглые шишки на растении' (цит. по ЕСУМ, I: 298);

русск. диал. балабо́лка 'плод картофеля с семенами, вырастающий на стебле после цветения' и 'цветок колокольчик', 'водяная лилия', 'расте- 
ние лютик', 'небольшая, очень сдобная лепешка', 'большая ягода', 'нарост на коже животного, человека; шишка...', 'шарообразный наконечник на палке', 'клок шерсти, свалявшийся с грязью (у скота)' и др. (СРНГ, II: 66);

н.-луж. kulka 'картофель' и 'шарик', 'клецки как блюдо (из муки, картофеля и тем подобные)', 'щиколка на ноге или руке', 'головка булавки' (MUKA, I: 740).

\section{4. Гипотеза о происхождении слов}

Отмеченные особенности цитированных славянских названий картофеля: редупликация, формальная и семантическая вариативность, случаи нарушения фонетических законов, относительное единообразие форм, которое способствуется редупликацией, контаминация, говорят в пользу того, что они могут быть наследниками звукоизобразительных этимонов, и точнее, звукосимволических (Систематизацию и анализ признаков звукосимволических слов см. в КОЛЕВА-ЗЛАТЕВА 2008: 54-76, где цитированы и другие авторы). Такое предположение подкрепляется также наблюдаемым формально-семантическим параллелизмом, состоящим в выражении одних и тех же значений формами с редупликацией. Формальное и семантическое сходство слов говорит о примарной связи между их формой и значением, т.е. о их фонетической мотивированности. Судя по выражаемым данными словами значениям, для их звукосимволических этимонов можно предположить первоначальное значение 'маленький шарообразный предмет', от которого могут быть получены все остальные значения. Такое значение выражается некоторыми из рассматриваемых слов, называющих картофель, как сербохорв. bóba 'что-либо маленькое, округлое', укр. бібка 'шарик маленький', бомбулька 'маленький шарообразный предмет', н.-луж. kulka 'шарик'. В типологическом плане ср. также с чешск. bambule, bambula, dem. bambulka 'что-либо круглое', словацк. bambolec, bombolec, brmbolec 'то же' (цит. по MACHEK 1968: 44), болг. пу́nолец 'шарообразный предмет', пупу́лчя 'шарик' (ГЕPOB, IV: 398), лит. диал. burbulas 'шарик, кусок', bambolikas 'предмет овальной формы, колобок', karkólas 'шарик; колобок’ (LKŽ), рум. gogoloi 'маленький шарообразный предмет' (DEX 2009) и др.

Следовательно, рассматриваемые названия картофеля свидетельствуют о том, что в нередких случаях славяне называли клубни нового овоща «маленькими шариками», используя существующие звукосимволическе экспрессивные слова, возможно, выражая при этом и ироническое отношение к иноземному овощу, о чем, как было отмечено выше, существуют и другие свидетельства. 


\section{Литература}

БАЙКОЎ - НЕКРАШЭВІЧ 1925 = БАЙКОЎ М. - НЕКРАШЭВІЧ С. (УКл.). Беларуска-расійскі слоўнік. Менск, 1925. Факсімільнае выданьне: Менск, 1993. <http://slounik.org/bn> (26.11.2016)

БЕР = Български етимологичен речник. София, 1971-

БРОКГАУЗ - ЕФРОН 1895 = БРОКГАУЗ Ф.А. - ЕФРОН И.А. (изд.). Энциклопедический словарь. Т. XIV. С.-Пб, 1895.

ГЕРОВ $=$ ГЕРОВ Н. Речник на българския език. Фототипно изд. Т. I-VI. T. VI събрал, наредил и изтьлкувал Т. Панчев. София. (1895-1908), 1975-1978.

ГРИГОРЬЕВ 1861 = ГРИГОРЬЕВ, В.В. Руководство к ботанике. В двух частях. Москва, 1961.

ГРИНЧЕНКО = ГРИНЧЕНКО Б. (упор.). Словар української мови. T. I-IV, Київ, 1907-1909.

ДАЛЬ = ДАЛЬ Вл. Толковый словарь живого великорусского языка. $<\mathrm{http}: / /$ slovardalja.net/> (10.11.2016)

ЕСУМ = Етимологічний словник української мови. У 7-ми т. Т. I-V. АН УРСР. Мельничук, О.С. (головн. ред.). Т. I-V. Київ, 1982-2006.

ЖЕЛЕХОВСКИЙ - НЕДїЛЬСКИЙ = ЖЕЛЕХОВСКИЙ Є., НЕДЇЛЬСКИЙ С. Малоруско-нїмецкий словар: У 2-х т. Львів, 1886.

КОЛЕВА-ЗЛАТЕВА 2008 = КОЛЕВА-ЗЛАТЕВА Ж. Славянская лексика звукосимволического происхождения // Tractata Slavica Universitatis Debreceniensis. Vol. 1. Ред. серии К. Адягаши. Дебрецен, 2008.

МЛАДЕНОВ 1967 = МЛАДЕНОВ М. Лексиката на ихтиманския говор // Българска диалектология. Проучвания и материали. Т. ІІІ. София, 3-196.

РУДНИЦЬКИЙ = РУДНИЦЬКИЙ Я. (укл.) Етимологічний словник української мови: У 2-х т. Укл. Я. Рудницький. Вінніпег-Оттава, 1962-1982.

СРНГ = Словарь русских народных говоров. Т. $1-$ (ред. Ф.П. Филин, Ф.П. Сороколетов), Ленинград, $1965-$.

СТОЙКОВ 1993 = СТОЙКОВ Ст. Българска диалектология. София, 1993.

ANDAGOYA $1865=$ DE ANDAGOYA P. Narrative of the proceedings of Pedrarias Dávila in the provinces of Tierra Firme or Catilla del Oro: and of the discovery of the South Sea and the coasts of Peru and Nicaragua. London: Hakluyt Society, 1865.

CIEZA DE LEÓN 2005 = DE CIEZA DE LEÓN P.. Cronica del Peru. El Senorio de los Incas. Fundación Biblioteca Ayacucho, 2005.

DEX 2009 = Dicţionarul explicativ al limbii române, editat de Academia Română şi Institutul de Lingvistică "Iorgu Iordan", ediţia a II-a, 1998. <http://dexonline.ro/> (24.11.2016)

KLUGE 1889 = KLUGE FR. Etymologisches Wörterbuch der Deutschen Sprache. Straßburg, 1889.

KORANDOVÁ $1962=$ KORANDOVÁ M. O českých nářečních názvech pro brambory // Naše řeč, vol. 45 (1962), issue 5-6, 181-191.

LKŽ = Lietuvių kalbos žodynas. T. I-XX. Vilnius, 1941-2002 $<$ http://www.lkz.lt/dzl.php?1> (24.11.2016)

MACHEK 1968 = MACHEK V. Etymologický slovník jazyka českého. Druhé, opravené a doplněné vydáni. Praha, 1968 
MALKIEL 1990 = MALKIEL Y. Diachronic Problems in Phonosymbolism // Edita and Inedita, 1979-1988. Vol. 1. Amsterdam/Phyladelphia: John Benjamins Publishing Company.

MEW = MIKLOSICH F. Etymologisches Wörterbuch der slawischen Sprachen. Wien: Wilhelm Braumüller, 1886.

MUKA = MUKA E. Słownik dolnoserbskeje rěcy a jeje narěcow. I-II. Reprint 1966. Petrohrad, 1911-1915, Praha, 1926, 1928.

OED = HARPER, DOUGLAS. Online Etymology Dictionary. < http://www.etymonline.com/> (07.11.2016)

PFUHL = PFUHL Chr. Tr. Obersorbisches Wörterbuch. Bautzen 1866 . Fotomechanischer Neudruck. Bautzen, 1968.

PLETERŠNIK = PLETERŠNIK M. Slovensko-nemški slovar. Ljubljana, 1894-1895.

PSJČ = Př́ruční slovník jazyka českého. I-IX. Praha, 1935-1957. $<$ http://psjc.ujc.cas.cz/> (10.11.2016)

REJZEK 2001 = Rejzek J. Český etymologicky slovník. Leda, 2001

RJA = Rječnik hrvatskoga ili srpskoga jezika. I-XXII. Zagreb. 1880-1975.

SSJ = Slovník slovenského jazyka. Ved. red. Št. Peciar. I-VI. Bratislava, 1959-1968.

WARSZ = KARŁOWICZ J., KRYŃSKI A., NIEDŹWIEDZKI W. Słownik języka polskiego. T. I - VIII. Warszawa, 1900-1927. 